\title{
Exclusive Postsynaptic Action of Hypocretin-Orexin on Sublayer 6b Cortical Neurons
}

\author{
Laurence Bayer, ${ }^{1}$ Mauro Serafin, ${ }^{1}$ Emmanuel Eggermann, ${ }^{1}$ Benoît Saint-Mleux, ${ }^{1}$ Danièle Machard, ${ }^{1}$ Barbara E. Jones, ${ }^{2}$ \\ and Michel Mühlethaler ${ }^{1}$ \\ ${ }^{1}$ Département de Physiologie, Centre Médical Universitaire, 1211 Genève 4, Switzerland, and ²Department of Neurology and Neurosurgery, McGill \\ University, Montreal Neurological Institute, Montreal, Quebec, Canada H3A 2B4
}

The hypocretin- orexin (hcrt-orx) neurons are thought to maintain wakefulness because their loss results in narcolepsy. This role may be fulfilled by the excitatory action that the hcrt-orx peptide exerts on multiple brainstem and forebrain systems that, in turn, promote cortical activation. Here, we examined whether hcrt- orx may also exert a postsynaptic excitatory action at the level of the cortex, where hcrt- orx fibers project. However, we found that neurons in layers 2-5 in the primary somatosensory cortex (SSp) were unresponsive to hcrt- orx. We then found that although all neurons tested in sublayer 6a were also unresponsive to hort- orx, all those tested in sublayer $6 \mathrm{~b}$ were highly sensitive to the peptide. The sublayer selectivity of hcrt- orx was not restricted to the somatosensory cortex, because it was also found to be present in the primary visual cortex, the motor cortex, and the cingulate cortex. In the SSp, in which the hcrt- orx effect was investigated further, it was demonstrated to be postsynaptic, to result from an interaction with Hcrtr2-OX $\mathrm{X}_{2}$ receptors and to depend on the closure of a potassium conductance. Similar to the selectivity of action in the thalamus, where hcrt- orx excites the nonspecific thalamocortical projection neurons and not the specific sensory relay neurons, here in the cortex, it excites a specific subset of cortical neurons which, through corticocortical projections, may also be involved in promoting widespread cortical activation.

Key words: arousal; cortex; hypocretin; orexin; sleep; waking

\section{Introduction}

The neurons of the lateral hypothalamus and perifornical area that express hypocretin-orexin (hcrt-orx) (de Lecea et al., 1998; Sakurai et al., 1998) are thought to play a major role in promoting the state of wakefulness (for review, see Siegel et al., 2001; Beuckmann and Yanagisawa, 2002; Sutcliffe and de Lecea, 2002; Taheri et al., 2002). Indeed, various conditions that interfere with the integrity of the neurons, the peptides they secrete, or the receptors to the peptides are associated with a deficiency in wakefulness and the development of narcolepsy (Chemelli et al., 1999; Lin et al., 1999; Nishino et al., 2000; Peyron et al., 2000; Thannickal et al., 2000; Hara et al., 2001). The hcrt-orx neurons synthesize two peptides (hypocretin 1 and hypocretin 2; also known as orexin $\mathrm{A}$ and $\mathrm{B})$ that act on two types of receptors $\left(\mathrm{OX}_{1}\right.$ and $\mathrm{OX}_{2}$; also known as Hcrtr1 and Hcrtr2) (Sakurai et al., 1998). These receptors are expressed widely throughout the CNS, including the cerebral cortex (Lu et al., 2000; Marcus et al., 2001), to where the hcrt-orx fibers also project (Peyron et al., 1998; van den Pol, 1999). Hypocretin-orexin receptors and fibers are particularly densely distributed in areas known to be involved in promoting wakefulness by stimulating cortical activation (for re-

Received June 27, 2003; revised June 11, 2004; accepted June 13, 2004.

This work was supported by grants from the Swiss Fonds National, Novartis, 0TT, de Reuter, Roche, Schmidheiny Foundations (M.M., M.S.), the Canadian Medical Research Council (B.E.J.), and a Roche fellowship (L.B.).

Correspondence should be addressed to Dr. M. Mühlethaler, Centre Médical Universitaire Département de Physiologie, 1 Rue Michel-Servet, 1211 Genève 4, Switzerland. E-mail: michel.muhlethaler@medecine.unige.ch. DOI:10.1523/JNEUROSCI.1783-04.2004

Copyright $\odot 2004$ Society for Neuroscience $\quad$ 0270-6474/04/246760-05\$15.00/0 view, see Steriade and McCarley, 1990; McCormick and Bal, 1997; Jones, 2000, 2003; Steriade, 2000). Hcrt-orx peptides have been shown to exert excitatory actions on many of these systems, including noradrenergic locus coeruleus neurons, histaminergic neurons, and cholinergic mesopontine and basal forebrain neurons (Hagan et al., 1999; Horvath et al., 1999; Bourgin et al., 2000; Ivanov and Aston-Jones, 2000; Methippara et al., 2000; Bayer et al., 2001; Eggermann et al., 2001; Eriksson et al., 2001; Huang et al., 2001; Xi et al., 2001; Brown et al., 2002; Burlet et al., 2002). In a recent study, we have shown that thalamic neurons of the intralaminar and midline nuclei, which comprise the nonspecific thalamocortical projection system, and not those of the specific relay nuclei, are also excited by hcrt-orx (Bayer et al., 2002). Interestingly, hcrt-orx has an excitatory effect on the terminals of those same thalamic neurons in the cortex (Lambe and Aghajanian, 2003). In the present study, we examined whether hcrt-orx may also excite cortical neurons by a direct postsynaptic action. Using cortical slices from different regions, we tested the effect of the hcrt-orx peptides on neurons in different layers of the primary somatosensory cortex (SSp), the primary visual cortex (VISp), the primary motor cortex (MOp), and the cingulate cortex (CG).

\section{Materials and Methods}

Electrophysiological recordings. Brain slices were obtained from young rats (15-25 d of age) reared at the animal facility of the Geneva Medical Centre and treated according to the regulations of the Swiss Federal Veterinary Office. Coronal slices (250-300 $\mu \mathrm{m}$ thick) that included the cerebral cortex (Swanson, 1992) were incubated at room temperature in 
artificial CSF (ACSF), which contained (in $\mathrm{mm}$ ): $130 \mathrm{NaCl}, 5 \mathrm{KCl}, 1.25 \mathrm{KH}_{2} \mathrm{PO}_{4}, 1.3$ $\mathrm{MgSO}_{4}, 20 \mathrm{NaHCO}_{3}, 10$ glucose, and 2.4 $\mathrm{CaCl}_{2}$, bubbled with a mixture of $95 \% \mathrm{O}_{2}$ and $5 \% \mathrm{CO}_{2}$. Experiments in which $E_{\mathrm{K}}$ was changed were done with the following ACSF (in $\mathrm{MM}$ ): $124.25 \mathrm{NaCl}, 10.75 \mathrm{KCl}, 1.25 \mathrm{KH}_{2} \mathrm{PO}_{4}, 1.3$ $\mathrm{MgSO}_{4}, 20 \mathrm{NaHCO}_{3}, 10$ glucose, and 2.4 $\mathrm{CaCl}_{2}$. According to the Nernst equation $\left[E_{\mathrm{K}}=\right.$ $\left.2.303(R T / z F) \cdot \log \left(K_{\mathrm{o}} / K_{\mathrm{i}}\right)\right]$ was $-77.8 \mathrm{mV}$ in the control ACSF $\left(K_{\mathrm{o}}=6.25 \mathrm{mM}\right)$ and -61.0 $\mathrm{mV}$ in the modified ACSF $\left(K_{\mathrm{o}}=12 \mathrm{mM}\right)$. Individual slices were transferred to a thermoregulated $\left(32^{\circ} \mathrm{C}\right)$ chamber on a Zeiss (Oberkochen, Germany) Axioskop equipped with an infrared camera (Dodt and Zieglgansberger, 1994). Slices were maintained immersed and continuously superfused at $3-5 \mathrm{ml} / \mathrm{min}$. Patch electrodes were pulled on a DMZ universal puller (Zeitz-Instrumente, Münich, Germany) from borosilicate glass capillaries (GC150F-10; Clark Electromedical Instruments, Pangbourne, UK). The pipettes (5-10 M $\Omega$ ) contained the following solution (in $\mathrm{mm}$ ): $126 \mathrm{KMeSO}_{4}, 8$ phosphocreatine, $4 \mathrm{KCl}, 5 \mathrm{MgCl}_{2}, 10 \mathrm{HEPES}, 3$ $\mathrm{Na}_{2}$ ATP, 0.1 GTP, and 0.1 BAPTA, pH 7.4 (290-310 mOsm). Neurobiotin (0.2\%; Vector Laboratories, Burlingame, CA) was added to the intrapipette solution when needed. Current-clamp and voltage-clamp recordings were obtained in the whole-cell configuration using an Axopatch $200 \mathrm{~B}$ and pClamp 8.0 software (Axon Instruments, Foster City, CA). Liquid junction potential $(-9 \mathrm{mV})$ was calculated using JPCalc (bundled in the Axon software). Current-voltage plots ( $I-V$ curves) were obtained in the presence of tetrodotoxin (TTX; $1 \mu \mathrm{M}),(+)-5$-methyl-10,11-dihydro-5H-dibenzo [a,d] cyclohepten-5,10-imine maleate $(20 \mu \mathrm{M})$, and APV $(50 \mu \mathrm{M})$ before and during hcrt2-orxB application using slow (6 sec) ramps between +20 and $-120 \mathrm{mV}$. Ramps were generated and analyzed using pClamp 8.0 software.

Hcrt-orx (Bachem, Bubendorf, Switzerland) peptides were tested by dissolving them at the proper concentration in the perfusion solution. Input resistance was occasionally monitored throughout the pharmacological experiments using short-lasting hyperpolarizing current pulses. At the maximum of the depolarizing effect of the hort-orx, the membrane potential was clamped manually back to its resting value, thus allowing evaluation of the change in membrane resistance.

Histology. After electrophysiological recordings, slices were fixed in an ice-cold solution containing 3\% paraformaldehyde. Neurobiotin-filled neurons were then visualized using the avidin-biotinylated horseradish peroxydase complex reaction (Vectastain, ABC Elite kit; Vector Laboratories) with 3-3' -diaminobenzidine (Sigma, St. Louis, MO) as a chromogen. To distinguish the location of stained cells within cortical layers, slices were counterstained with $0.3 \%$ of toluidin blue. Photomicrographs were realized with a digital microscope camera (Axiocam; Zeiss) and printed with Photoshop 6.0 (Adobe Systems, San Jose, CA).

\section{Results}

Neurons of cortical sublayer 6 b of the SSp are selectively exited by hcrt-orx

Cortical neurons of the SSp (Fig. $1 A$ ) were visualized by infrared video-microscopy and tested for their sensitivity to bath application of hcrt-orx (10-500 nM). As illustrated in Figure $1 B-D$, we found most cortical neurons of layers $2-5$ to be unresponsive to hcrt-orx (as judged by monitoring membrane potential, membrane resistance, and changes in the occurrence of synaptic po- tentials). To ensure the validity of these negative results, most studies were conducted with orxA, which is as potent as orx B on Hcrt2- $\mathrm{OX}_{2}$ receptors but more active than orxB on Hcrt1-OX receptors (Sakurai et al., 1998). Starting from the surface, we found, as illustrated in Figure $1, B_{1}$ and $B_{2}$, that 21 of 21 cells estimated to be in layers 2-3 were unresponsive (nine tested with orxA at $100 \mathrm{~nm}$, four with orxA at $500 \mathrm{nM}$, and eight with orxB at $100 \mathrm{nM}$ ). In layers $4-5$ (Fig. $1 C_{1}, C_{2}$ ), 28 of 31 cells showed no response to hcrt-orx (20 tested with orxA at $100 \mathrm{nM}, 5$ with orxA at $500 \mathrm{nM}$, and 3 with orxB at $100 \mathrm{~nm}$ ). In 3 of 31 cells of layer 4/5, a minute depolarization was found that resulted from an increase in spontaneous synaptic potentials (Fig. $1 G$, middle panel). The synaptic potentials and depolarization were eliminated by either TTX or in modified ACSF $\left(0.1 \mathrm{mM} \mathrm{Ca}^{2+} / 10 \mathrm{mM} \mathrm{Mg}^{2+}\right)$ known to block synaptic transmission ( $n=2$ of 2 ) (Fig. $1 G$, right panel).

In contrast to the negative results in layers $2-5$, neurons responsive to hcrt-orx were found in layer 6 . However, even within that layer, the responsive cells were limited in their distribution. Indeed, as evident under infrared video-microscopy, all of the responsive cells were located within layer $6 \mathrm{~b}$, which is separated from layer $6 \mathrm{a}$ by a thin horizontal band of fibers (Fig. $1 \mathrm{~A}$, asterisk). In layer $6 \mathrm{a}$ (Fig. $1 D_{1}, D_{2}$ ) eight of nine neurons tested were insensitive to hcrt-orx (two tested with orxA at $100 \mathrm{nM}$, and six with orxB at $100 \mathrm{~nm}$ ). One neuron was slightly depolarized by orxB at $100 \mathrm{~nm}$. Two unresponsive cells were injected with neurobiotin and confirmed by histochemistry to be located in sublayer 6 a (Fig. $1 F_{1}$, from cell 1 in $A$ ). In contrast (Fig. $1 E_{1}, E_{2}$ ), all 
A

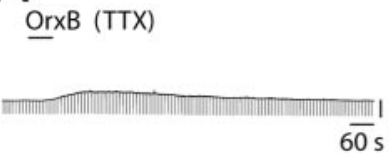

B

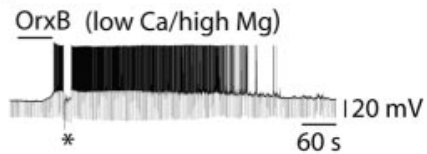

$C_{1}$

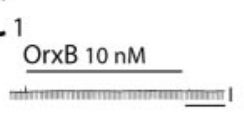

3

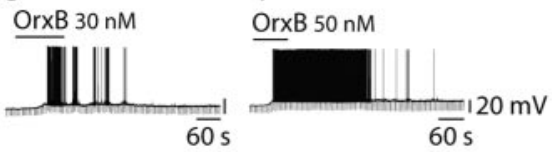

$\mathrm{D}$

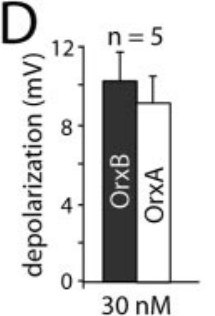

Figure 2. Mechanism of action of hert- orx on SSp sublayer $6 \mathrm{~b}$ cortical neurons. $A, B, \mathrm{Re}$ sponse to hcrt-orx in the presence of TTX at $1 \mu \mathrm{m}(A)$ or in the presence of a modified ACSF containing $0.1 \mathrm{~mm} \mathrm{Ca}^{2+}$ and $10 \mathrm{~mm} \mathrm{Mg}^{2+}(B)$. C, Dose-responses to hcrt2-orxB applied between 10 and $50 \mathrm{~nm}$. D, Comparison of the depolarization induced by hert1- orxA and hcrt2orxB (applied at $30 \mathrm{~nm}$ ).

cells ( 37 of 37 ) tested in sublayer $6 \mathrm{~b}$ were excited by hcrt-orx (27 tested with $100 \mathrm{~nm}$ orxB, 9 with $500 \mathrm{~nm}$ orxB, and 1 with $100 \mathrm{nM}$ orxA). Eight cells depolarized by hcrt-orx and visualized in sublayer $6 \mathrm{~b}$ were labeled with neurobiotin and confirmed to be localized within that sublayer (Fig. $1 F_{2}$, from cell 2 in $A$ ).

Hcrt-orx excitation of sublayer $6 \mathrm{~b}$ neurons in the SSp cortex is postsynaptic and involves $\mathrm{Hcrtr} 2-\mathrm{OX}_{2}$ receptors

The hcrt-orx depolarization was further characterized in SSp cortical neurons of sublayer $6 \mathrm{~b}$. It was found that the effect persists in the presence of either TTX $(1 \mu \mathrm{M} ; n=4$ of 4$)$ (Fig. $2 A)$ or in a modified $\operatorname{ACSF}\left(0.1 \mathrm{mM} \mathrm{Ca}^{2+} / 10 \mathrm{mM} \mathrm{Mg}^{2+} ; n=3\right.$ of 3 ) (Fig. $2 B)$ known to block synaptic transmission, thus indicating that the hcrt-orx action is postsynaptic. As illustrated in Figure $2 C$, the effects of hcrt-orx were dose dependent with a threshold above $10 \mathrm{~nm}$ for both hcrt1-orxA and hcrt2-orxB. We then explored the receptors involved in the depolarizing action of hcrtorx by comparing the effect of hcrt1-orxA with that of hcrt2orxB (Fig. 2D), both applied at $30 \mathrm{~nm}$, and found that the effects did not differ statistically (mean depolarization \pm SEM for hcrt1orxA $=9.2 \pm 1.67 \mathrm{mV}$ and for hort $2-$ orxB $=10.3 \pm 1.88 \mathrm{mV}$; $n=5$; paired $t$ test, $t=-0.436$; $p=0.674)$. Together, these results suggest that the hcrt-orx effect is caused by an action on Hcrtr2-OX 2 receptors (Sakurai et al., 1998).

Hcrt-orx depolarization of sublayer $6 \mathrm{~b}$ neurons in the SSp is attributable to the blocking of a potassium current

The depolarization by hcrt-orx was accompanied by a small increase in membrane input resistance (nine of nine cells) (Fig. $2 B$, asterisk). To test whether such an effect could result from the closure of a potassium conductance, we turned to voltage-clamp studies. In an ACSF with $K_{\mathrm{o}}$ at $6.25 \mathrm{~mm}$ (estimated $E_{\mathrm{K}}=-77.8$ $\mathrm{mV}$ ), comparing voltage-clamp ramps in control and in the presence of hcrt2-orxB (Fig. 3A, $C$, subtraction 1-2) indicated a reversal of the hcrt-orx effect of approximately $-80 \mathrm{mV}$. In five cells (Fig. $3 C$, inset), the mean $( \pm$ SEM) reversal was $-77.4 \pm$ $1.14 \mathrm{mV}$, thus very close to the estimated $E_{\mathrm{K}}$. Performing the same experiment (Fig. 3B, $C$, subtraction 3-4) in an ACSF with $K_{\mathrm{o}}$ at $12 \mathrm{~mm}$ (estimated $E_{\mathrm{K}}=-61.0 \mathrm{mV}$ ) indicated a reversal of the hcrt-orx effect of approximately $-60 \mathrm{mV}$. In five cells (Fig. $3 C$, inset), the mean reversal was now $-60.4 \pm 0.68 \mathrm{mV}$, thus

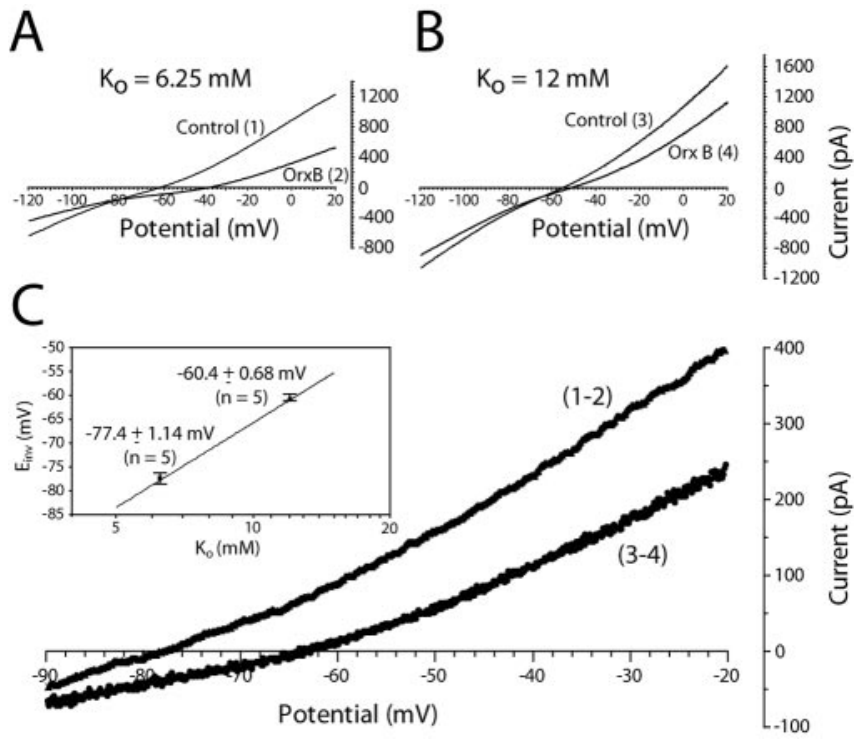

Figure 3. Hcrt-orx blocks a K current. $A$, Voltage-clamp ramps in absence (1) or presence (2) of hert-orx with $\mathrm{K}_{0}$ at $6.25 \mathrm{~mm}$. $B$, Voltage-clamp ramps in absence (3) or presence (4) of hcrt-orx with $\mathrm{K}_{0}$ at $12.0 \mathrm{~mm}$. C, Subtractions of curves from $A(1,2)$ and $B(3,4)$. Inset, Reversal potentials for both conditions with respect to Nernst relationship (see Materials and Methods).

again very close to the estimated $E_{\mathrm{K}}$. These data thus indicate that the hcrt-orx effect in the SSp is mediated through the closure of a potassium conductance.

\section{Selective action of hcrt-orx in other cortical areas}

We subsequently investigated whether the selectivity of the hcrtorx effects to layer $6 \mathrm{~b}$ in the SSp was also present in other cortical areas. Thus, we first tested hcrt-orx on cortical neurons in another sensory field, the VISp, and found that in cortical layers $2-6$ a, no cells ( 27 of 29 ) were directly depolarized by either orxA ( 11 of 11 at $100 \mathrm{nM}$, and 9 of 9 at $500 \mathrm{~nm}$ ) or orxB (7 of 7 at 100 $\mathrm{nM}$ ). As in the SSp, however, a small minority of cells (2 of 29) showed an increase in spontaneous synaptic potentials (in that case, in layer $6 \mathrm{a}$, with $100 \mathrm{~nm}$ of orxB). In contrast, all neurons of sublayer $6 \mathrm{~b}$ were depolarized by hcrt-orx (five of five tested with orxB at $100 \mathrm{~nm}$ ) (Fig. 4A).

Next, we tested hcrt-orx on neurons of another type of cortex, the MOp, and found similar results with no cells (29 of 29) in layers 2-6a being sensitive to either orxA (16 of 16 at $100 \mathrm{nM}$, and 5 of 5 at $500 \mathrm{nM}$ ) or orxB ( 8 of 8 at $100 \mathrm{nM}$ ), whereas all cells in sublayer $6 \mathrm{~b}$ were depolarized (four of four with orxB at $100 \mathrm{nM}$ ) (Fig. $4 B_{1}$ ).

Finally, we tested hcrt-orx in a nonmotor, nonsensory cortex, the CG, and again found similar results with 38 of 39 cells in layers 2-6a being insensitive to either orxA ( 13 of 13 at $100 \mathrm{nM}$, and 9 of 9 at $500 \mathrm{~nm}$ ) or orxB (16 of 16 at $100 \mathrm{~nm})$. One cell of 39 showed an increase in spontaneous synaptic potentials. As in the other cortices, all cells in sublayer $6 \mathrm{~b}$ were depolarized by hcrt-orx (four of four with orxB at $100 \mathrm{~nm}$ ) (Fig. $4 B_{2}$ ).

\section{Discussion}

The present study demonstrates that in all cortical regions tested, neurons showed excitatory postsynaptic responses to hcrt-orx. However, these responses occurred exclusively in neurons of sublayer 6b. As studied in detail within the SSp, the excitatory effect was found to be mediated by Hcrtr2- $\mathrm{OX}_{2}$ receptors and caused by the closure of a potassium conductance.

Many studies have shown that hcrt-orx exerts an excitatory 


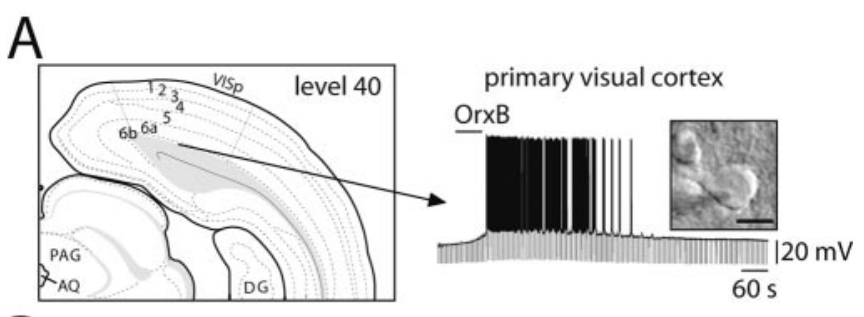

B

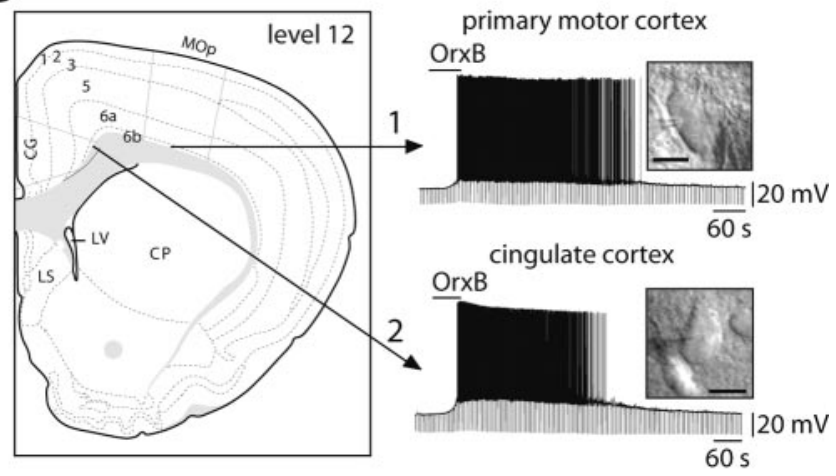

Figure 4. Exclusive action of hert- orx in sublayer $6 \mathrm{~b}$ in primary visual cortex, primary motor cortex, and cingulate cortex. $A, B$, Excitatory action of hcrt- orx on sublayer $6 \mathrm{~b}$ neurons of the primary visual cortex $(A)$, primary motor cortex $\left(B_{1}\right)$, and cingulate cortex $\left(B_{2}\right)$. Scale bar, $15 \mu \mathrm{m}$ (in all insets showing infrared images of recorded cells). $A Q$, Aqueduct; $(P$, caudate-putamen; $D G$, dentate gyrus; $L S$, lateral septum; LV, lateral ventricle; PAG, periacqueductal gray.

action on CNS neurons (for review, see Sutcliffe and de Lecea, 2002). The receptors mediating these actions vary across cell groups but are commonly of the Hcrtr2- $\mathrm{OX}_{2}$ subtype within the subcortical arousal systems (Eriksson et al., 2001; Bayer et al., 2002; Brown et al., 2002; Burlet et al., 2002), except those on locus

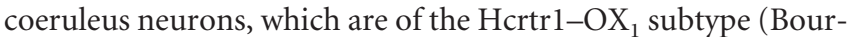
gin et al., 2000). Here in the cortical neurons of layer 6b, the equivalent effect of hcrt1-orxA and hcrt2-orxB also suggests the effect is mediated by Hcrtr2-OX 2 receptors (Sakurai et al., 1998). This assumption is supported by histochemical evidence showing a higher density of Hcrtr2- $\mathrm{OX}_{2}$ than Hcrtr1-OX $\mathrm{O}_{1}$ receptors in the cortex and a higher density of the Hcrtr2- $\mathrm{OX}_{2}$ receptors in the deep than in the superficial layers of the cortex (Marcus et al., 2001). The excitatory action mediated by hcrt-orx receptors has been shown to involve several mechanisms, including an electrogenic pump and calcium current in histaminergic neurons (Eriksson et al., 2001) and a nonselective cation conductance in mesopontine cholinergic (Burlet et al., 2002) and serotoninergic dorsal raphe neurons (Brown et al., 2002). As was the case in thalamic neurons of the diffuse thalamocortical projection system (Bayer et al., 2002), we found here that the depolarization induced by hcrt-orx in the cortical neurons was attributable to block of a potassium conductance.

The excitatory action of hcrt-orx on subcortical arousal systems, including the noradrenergic, histaminergic, cholinergic mesopontine, and basal forebrain cell groups has been emphasized as the principal way in which this peptide may promote behavioral arousal and cortical activation to maintain wakefulness (Hagan et al., 1999; Horvath et al., 1999; Bourgin et al., 2000; Ivanov and Aston-Jones, 2000; Methippara et al., 2000; Bayer et al., 2001; Eggermann et al., 2001; Eriksson et al., 2001; Huang et al., 2001; Xi et al., 2001; Brown et al., 2002; Burlet et al., 2002). In addition, we demonstrated an excitatory action on the thalamic neurons of the nonspecific thalamocortical projection system
(Bayer et al., 2002), which evokes widespread cortical activation (Steriade, 1981), and Lambe and Aghajanian (2003) demonstrated an excitatory presynaptic action on the terminals of that system in the cortex. Here, we show a direct postsynaptic excitatory effect of hcrt-orx on cortical neurons. Interestingly, however, this effect is highly restricted to a small sublayer of cells, layer $6 \mathrm{~b}$. These data are in agreement with the little number of responsive cortical neurons as reported in cultures (van den Pol et al., 1998). Comparable with neurons of the nonspecific thalamocortical projection system, neurons in sublayer $6 \mathrm{~b}$ project in a widespread manner to the cortical mantle (Clancy and Cauller, 1999; Reep, 2000). Indeed, they send corticocortical projections particularly to layer 1 , which also receives input from nonspecific thalamocortical projection systems (Herkenham, 1986) and through which neurons in deeper cortical layers, including pyramidal cells, can be strongly influenced. Hcrt-orx could thus stimulate widespread cortical activation by direct actions on sublayer $6 \mathrm{~b}$ cortical neurons. The hcrt-orxinergic system would thus exert a powerful activating influence on the cortex by direct excitation of this corticocortical system, in parallel with its excitation of the nonspecific thalamocortical projection system and the cholinergic basalocortical and other subcortical arousal systems.

\section{References}

Bayer L, Eggermann E, Serafin M, Saint-Mleux B, Machard D, Jones BE, Mühlethaler M (2001) Orexins (hypocretins) directly excite tuberomammillary neurons. Eur J Neurosci 14:1571-1575.

Bayer L, Eggermann E, Saint-Mleux B, Machard D, Jones BE, Mühlethaler M, Serafin M (2002) Selective action of orexin (hypocretin) on nonspecific thalamocortical projection neurons. J Neurosci 22:7835-7839.

Beuckmann CT, Yanagisawa M (2002) Orexins: from neuropeptides to energy homeostasis and sleep/wake regulation. J Mol Med 80:329-342.

Bourgin P, Huitron-Resendiz S, Spier AD, Fabre V, Morte B, Criado JR, Sutcliffe JG, Henriksen SJ, de Lecea L (2000) Hypocretin-1 modulates rapid eye movement sleep through activation of locus coeruleus neurons. J Neurosci 20:7760-7765.

Brown RE, Sergeeva OA, Eriksson KS, Haas HL (2002) Convergent excitation of dorsal raphe serotonin neurons by multiple arousal systems (orexin/ hypocretin, histamine and noradrenaline). J Neurosci 22:8850-8859.

Burlet S, Tyler CJ, Leonard CS (2002) Direct and indirect excitation of laterodorsal tegmental neurons by hypocretin/orexin peptides: implications for wakefulness and narcolepsy. J Neurosci 22:2862-2872.

Chemelli RM, Willie JT, Sinton CM, Elmquist JK, Scammell T, Lee C, Richardson JA, Williams SC, Xiong Y, Kisanuki Y, Fitch TE, Nakazato M, Hammer RE, Saper CB, Yanagisawa M (1999) Narcolepsy in orexin knockout mice: molecular genetics of sleep regulation. Cell 98:437-451.

Clancy B, Cauller LJ (1999) Widespread projections from subgriseal neurons (layer VII) to layer I in adult rat cortex. J Comp Neurol 407:275-286.

de Lecea L, Kilduff TS, Peyron C, Gao X, Foye PE, Danielson PE, Fukuhara C, Battenberg EL, Gautvik VT, Bartlett FS, Frankel WN, van den Pol AN, Bloom FE, Gautvik KM, Sutcliffe JG (1998) The hypocretins: hypothalamus-specific peptides with neuroexcitatory activity. Proc Natl Acad Sci USA 95:322-327.

Dodt HU, Zieglgansberger W (1994) Infrared videomicroscopy: a new look at neuronal structure and function. Trends Neurosci 17:453-458.

Eggermann E, Serafin M, Bayer L, Machard D, Saint-Mleux B, Jones BE, Mühlethaler M (2001) Orexins/hypocretins excite basal forebrain cholinergic neurones. Neuroscience 108:177-181.

Eriksson KS, Sergeeva O, Brown RE, Haas HL (2001) Orexin/hypocretin excites the histaminergic neurons of the tuberomammillary nucleus. J Neurosci 21:9273-9279.

Hagan JJ, Leslie RA, Patel S, Evans ML, Wattam TA, Holmes S, Benham CD, Taylor SG, Routledge C, Hemmati P, Munton RP, Ashmeade TE, Shah AS, Hatcher JP, Hatcher PD, Jones DN, Smith MI, Piper DC, Hunter AJ, Porter RA, Upton N (1999) Orexin A activates locus coeruleus cell firing and increases arousal in the rat. Proc Natl Acad Sci USA 96:10911-10916.

Hara J, Beuckmann CT, Nambu T, Willie JT, Chemelli RM, Sinton CM, Sugiyama F, Yagami K, Goto K, Yanagisawa M, Sakurai T (2001) Ge- 
netic ablation of orexin neurons in mice results in narcolepsy, hypophagia, and obesity. Neuron 30:345-354.

Herkenham M (1986) New perspectives on the organization and evolution of nonspecific thalamocortical projections. In: Cerebral cortex (Jones EG, Peters A, eds), pp 403-445. New York: Plenum.

Horvath TL, Peyron C, Diano S, Ivanov A, Aston-Jones G, Kilduff TS, van den Pol AN (1999) Hypocretin (orexin) activation and synaptic innervation of the locus coeruleus noradrenergic system. J Comp Neurol 415:145-159.

Huang ZL, Qu WM, Li WD, Mochizuki T, Eguchi N, Watanabe T, Urade Y, Hayaishi O (2001) Arousal effect of orexin A depends on activation of the histaminergic system. Proc Natl Acad Sci USA 98:9965-9970.

Ivanov A, Aston-Jones G (2000) Hypocretin/orexin depolarizes and decreases potassium conductance in locus coeruleus neurons. NeuroReport 11:1755-1758.

Jones BE (2000) Basic mechanisms of sleep-wake state. In: Principles and practice of sleep medicine, Ed 3 (Kryger MH, Roth T, Dement WC, eds), pp 134-154. Philadelphia: Saunders.

Jones BE (2003) Arousal systems. Front Biosci 8:S438-S451.

Lambe EK, Aghajanian GK (2003) Hypocretin (orexin) induces calcium transients in single spines postsynaptic to identified thalamocortical boutons in prefrontal slice. Neuron 40:139-150.

Lin L, Faraco J, Li R, Kadotani H, Rogers W, Lin X, Qiu X, de Jong PJ, Nishino S, Mignot E (1999) The sleep disorder canine narcolepsy is caused by a mutation in the hypocretin (orexin) receptor 2 gene. Cell 98:365-376.

Lu XY, Bagnol D, Burke S, Akil H, Watson SJ (2000) Differential distribution and regulation of OX1 and OX2 orexin/hypocretin receptor messenger RNA in the brain upon fasting. Horm Behav 37:335-344.

Marcus JN, Aschkenasi CJ, Lee CE, Chemelli RM, Saper CB, Yanagisawa M, Elmquist JK (2001) Differential expression of orexin receptors 1 and 2 in the rat brain. J Comp Neurol 435:6-25.

McCormick DA, Bal T (1997) Sleep and arousal: thalamocortical mechanisms. Annu Rev Neurosci 20:185-215.

Methippara MM, Alam MN, Szymusiak R, McGinty D (2000) Effects of lateral preoptic area application of orexin-A on sleep-wakefulness. NeuroReport 11:3423-3426.

Nishino S, Ripley B, Overeem S, Lammers GJ, Mignot E (2000) Hypocretin (orexin) deficiency in human narcolepsy. Lancet 355:39-40.

Peyron C, Tighe DK, van den Pol AN, de Lecea L, Heller HC, Sutcliffe JG, Kilduff TS (1998) Neurons containing hypocretin (orexin) project to multiple neuronal systems. J Neurosci 18:9996-10015.

Peyron C, Faraco J, Rogers W, Ripley B, Overeem S, Charnay Y, Nevsimalova
S, Aldrich M, Reynolds D, Albin R, Li R, Hungs M, Pedrazzoli M, Padigaru M, Kucherlapati M, Fan J, Maki R, Lammers GJ, Bouras C, Kucherlapati R, Nishino S, Mignot E (2000) A mutation in a case of early onset narcolepsy and a generalized absence of hypocretin peptides in human narcoleptic brains. Nat Med 6:991-997.

Reep RL (2000) Cortical layer VII and persistent subplate cells in mammalian brains. Brain Behav Evol 56:212-234.

Sakurai T, Amemiya A, Ishii M, Matsuzaki I, Chemelli RM, Tanaka H, Williams SC, Richardson JA, Kozlowski GP, Wilson S, Arch JR, Buckingham RE, Haynes AC, Carr SA, Annan RS, McNulty DE, Liu WS, Terrett JA, Elshourbagy NA, Bergsma DJ, et al. (1998) Orexins and orexin receptors: a family of hypothalamic neuropeptides and $\mathrm{G}$ protein-coupled receptors that regulate feeding behavior. Cell 92:573-585.

Siegel JM, Moore R, Thannickal T, Nienhuis R (2001) A brief history of hypocretin/orexin and narcolepsy. Neuropsychopharmacology 25:S14-S20.

Steriade M (1981) Mechanisms underlying cortical activation: neuronal organization and properties of the midbrain reticular core and intralaminar thalamic nuclei. In: Brain mechanisms of perceptual awarness (Pompeiano O, Marsan A, eds), pp 327-377. New York: Raven.

Steriade M (2000) Corticothalamic resonance, states of vigilance and mentation. Neuroscience 101:243-276.

Steriade M, McCarley RW (1990) Braistem control of wakefulness and sleep. New York: Plenum.

Sutcliffe JG, de Lecea L (2002) The hypocretins: setting the arousal threshold. Nat Rev Neurosci 3:339-349.

Swanson LW (1992) Brain maps: structure of the brain. Amsterdam: Elsevier.

Taheri S, Zeitzer JM, Mignot E (2002) The role of hypocretins (orexins) in sleep regulation and narcolepsy. Annu Rev Neurosci 25:283-313.

Thannickal TC, Moore RY, Nienhuis R, Ramanathan L, Gulyani S, Aldrich M, Cornford M, Siegel JM (2000) Reduced number of hypocretin neurons in human narcolepsy. Neuron 27:469-474.

van den Pol AN (1999) Hypothalamic hypocretin (orexin): robust innervation of the spinal cord. J Neurosci 19:3171-3182.

van den Pol AN, Gao XB, Obrietan K, Kilduff TS, Belousov AB (1998) Presynaptic and postsynaptic actions and modulation of neuroendocrine neurons by a new hypothalamic peptide, hypocretin/orexin. J Neurosci 18:7962-7971.

Xi M, Morales FR, Chase MH (2001) Effects on sleep and wakefulness of the injection of hypocretin-1 (orexin-A) into the laterodorsal tegmental nucleus of the cat. Brain Res 901:259-264. 